Article

\title{
Pessimistic Tone in Earnings Announcement and CSR Disclosure: Exploring the Interacting Role of CEO Busyness
}

\author{
Sri Ningsih ${ }^{1, *}$, Iman Harymawan ${ }^{1}$, Nurul Fitriani ${ }^{1}$ and Brian Lam ${ }^{2}$ \\ 1 Department of Accounting, Airlangga University, Surabaya 60115, Indonesia; \\ harymawan.iman@feb.unair.ac.id (I.H.); nurul.fitriani-2017@feb.unair.ac.id (N.F.) \\ 2 Division of Business and Management, BNU-HKBU United International College, Zhuhai 519087, China; \\ brianmolam@uic.edu.hk \\ * Correspondence: sri.ningsih@feb.unair.ac.id
}

\section{check for}

updates

Citation: Ningsih, S.; Harymawan, I.; Fitriani, N.; Lam, B. Pessimistic Tone in Earnings Announcement and CSR Disclosure: Exploring the Interacting Role of CEO Busyness. Sustainability 2021, 13, 13645. https://doi.org/ $10.3390 /$ su132413645

Received: 26 October 2021

Accepted: 30 November 2021

Published: 10 December 2021

Publisher's Note: MDPI stays neutral with regard to jurisdictional claims in published maps and institutional affiliations.

Copyright: (c) 2021 by the authors. Licensee MDPI, Basel, Switzerland. This article is an open access article distributed under the terms and conditions of the Creative Commons Attribution (CC BY) license (https:// creativecommons.org/licenses/by/ $4.0 /)$.

\begin{abstract}
This study analyzes the relationship between the pessimistic tone in earnings announcements and CSR disclosures interacted by CEO busyness. This study used 191 observations from 74 firms listed on the Indonesia Stock Exchange and the Global Reporting Initiative (GRI) database from 2016-2019. Grounded in signaling theory, we hypothesize that a pessimistic tone in earning announcements will increase CSR disclosure. We also hypothesize that busy CEOs strengthen this relationship. We use the ordinary least squares to analyze and answer our hypotheses. This study showed that the use of a pessimistic tone in the income statement in the discussion report and management analysis (MD\&A) is related positively and significantly to CSR disclosure. This study also found that busy CEOs strengthen those relationships. Our implication is that CSR disclosure in our sample is only measured based on the information presented in the sustainability report. To the best of the authors' knowledge, this study is the first to investigate the relationship between the pessimistic tone in earning announcements and CSR disclosures interacted by CEO busyness. In addition, this study provides insight into current performance disclosure practices in MD\&A reports and CSR reports that managers can use to safeguard the firm's reputation.
\end{abstract}

Keywords: pessimistic tone; earnings announcement; busy CEO; CSR disclosure; corporate sustainability

\section{Introduction}

Business development scenarios where the owner is different from the manager trigger a higher level of information asymmetry. Transparency in disclosing firm information is needed to minimize information asymmetry [1], especially in a developing country such as Indonesia, where the level of business competitiveness is low. Based on [2], Indonesia ranked 48th among 61 countries. This ranking is lower than other countries in Southeast Asia, such as Thailand (28th), Malaysia (19th), and Singapore (4th), and indicates that Indonesia has serious problems related to business competition, industrial efficiency, and investments. The data show that many industrial sectors are dominated by particular market leader firms, with total assets of more than 30\% in the industrial sector [3]. Firms in countries with low business competitiveness, such as Indonesia, tend to cover up surplus information from outside parties in order to avoid government and investor scrutiny [4]. This has resulted in a low degree of transparency and an information asymmetry problem.

The Indonesian government, through a financial service authority regulation [5], obligates public firms to include a management discussion and analysis report (MD\&A Report) in their annual reports. The MD\&A report is used by managements to communicate with stakeholders regarding a firm's performance and future goals [6], including earnings analysis. This information is essential for users, because earnings are one of the most widely used benchmarks to assess firm performance. A firm's management analysis of earnings is presented in the comprehensive statements of income in MD\&A. Research in accounting related to narrative disclosure in annual reports has become a trend in recent years [7]. 
This is due to big data and new technologies used to analyze text automatically $[7,8]$. Previous research has discussed narrative disclosures that are associated with corporate social responsibility [9], CEO characteristics [6,7,10], firm performance [11,12], and market reactions [13].

Previous research conducted by the authors of [14] revealed that the analysis of earnings announcements in an MD\&A report could provide helpful information for stakeholders as a companion to quantitative information. On the other hand, however, it can also provide misleading information caused by the absence of regulations that govern the format or context of narrative disclosure in these reports, thus providing an opportunity for management to subjectively discriminate the contents of the report $[6,7,15]$. Users can judge the discretion of report content from the tone used. Therefore, managements seek to manage stakeholder perceptions using a tone according to their interests. On the other hand, according to signaling theory, the use of certain tones in earnings announcements aims to signal a firm's performance. Research by the authors of [14] investigated optimistic and pessimistic tones in earning announcements.

The existence of a financial service authority regulation [5] that obligates public firms to report MD\&A increases the level of transparency and reduces asymmetry information, as the report is a tool of communication for other parties. The reason a manager uses pessimistic tones while describing earning announcements is because they anticipate the risk of financial performance declining when economic and non-economic factors change, as compared to predictions in previous MD\&A reports [16]. The pessimistic tones indicate a better level of transparency, especially in developing nations such as Indonesia. On the other hand, the use of a pessimistic tone in earnings announcements can signal a decline in performance, which can reduce the image and legitimacy of the firm [16]. To cover this, firms make voluntary disclosures (for example, CSR disclosure), both for financial and non-financial aspects, to give the impression of transparency [17]. CSR disclosure is an effective tool to strengthen corporate image [18], manage reputation risk [19], and reduce potential legitimacy gaps [17]. Using better CSR disclosure will help firms cover the risk of a decline in financial performance, be able to distract stakeholders, and maintain the firm's reputation.

Different from previous research [16,20], the focus of this study is to look at the relationship between the pessimistic tone in earnings announcements in an MD\&A report and the disclosure of corporate social responsibility (CSR). In addition, this study considers CEO busyness in the relationship between pessimistic tones and CSR disclosure. CEO busyness is an exciting and vital part of the Indonesian market, where $50 \%$ of CEOs of public firms listed on the Indonesia Stock Exchange have several positions in other firms [21]. The number of positions held by a CEO indicates their quality and reputation [22]. However, CEO busyness can also adversely affect their performance. Busy CEOs are quite prone to not being able to carry out functions properly due to limited energy and time [23,24], encouraging the use of a more robust pessimistic tone as a signal that the firm performance is declining.

Furthermore, this research was conducted in Indonesia as a developing country with a high level of information asymmetry due to the low level of business competitiveness. Indonesia also has CSR disclosure obligations regulated in Article 10 Clause (1) of [25], which states that LJK, issuers, and public firms must compile sustainability reports. However, this rule only came into effect in 2021; thus, during our research, CSR disclosure was still voluntary. As such, the preparation of CSR disclosures depends on the intentions and desires of each company. Furthermore, the research results of [26] explained that the quality of CSR disclosure in Indonesia is lower than in other ASEAN countries. For example, only $51.0 \%$ of public firms in Indonesia disclose CSR information in the annual report. Thus, $49 \%$ of public firms in Indonesia have no concern about disclosing CSR information in their annual reports. This condition can encourage CSR disclosure to be a greenwashing practice carried out by companies to cover the decreasing of company reputation since management use pessimistic language in the MD\&A report. Therefore, we are motivated 
to investigate whether companies will increase CSR disclosure when a pessimistic tone is used in the MD\&A report.

As such, this study used a sample of all listed firms on the Indonesia Stock Exchange (IDX) and the Global Reporting Initiative (GRI) during the period 2016-2019 and found that the pessimistic tone in earnings announcements is positively related to CSR disclosure. It means that management is motivated to use better CSR disclosure as a greenwashing practice to distract external party attention and maintain the firm's reputation when the manager considers the risk of financial declining through pessimistic tones in earning announcements aligned with signaling theory. In addition, this study also found that the presence of a busy CEO strengthens the relationship between pessimistic tone earnings disclosures and CSR disclosures.

This study has contributed in several ways. First, it contributes to the literature on narrative disclosure and sustainability disclosure. Then, it tries to explain the relationship between pessimistic tone in earnings announcement and CSR disclosure. It helps users identify the tone or style of language used to disclose the income statement narrative in the MD\&A report. In fact, the existence of an MD\&A report increases the degree of firm expectation from external parties and the level of pessimistic tone in earning announcements used to minimize their expectation. To convince stakeholders that the company is in a sustainable condition, management provides better CSR as a part of greenwashing practice.

Second, this study also provides practical implications for governments, investors, and all stakeholders interested in CSR and narrative disclosure. For the government, it can consider the findings from this study as to the importance of the outline in MD\&A reports due to there being no guidance in writing MD\&A reports in Indonesian financial authority regulation. The existence of an outline will help facilitate measuring MD\&A report compliance and maintain the level of transparency. Meanwhile, for investors, research results can be used to pay attention to the possible specific signals from the use of tone in the narrative reported by the company's management and its impact on financial and non-financial performance.

\section{Literature Review and Hypothesis Development}

\subsection{Pessimistic Tone in Earnings Announcement}

Asymmetric information between managers and outsiders is a big concern for investors, because it may cause adverse selection and agency costs. Thus, investors tend to require a premium as compensation for this information risk, which, in turn, leads to higher costs of capital and lower firm value $[27,28]$. A manager who acts in shareholders' interest may want to reduce the information risk [29] by privately signaling the market through corporate narrative disclosures [30].

$\mathrm{Li}$ [31] finds that the tone of forward-looking statements in management and discussion analysis (MD \&A) section of $10-\mathrm{K}$ and $10-\mathrm{Q}$ reports reflects future performance. Refs. [32-34] show that investors react to the tone in 10-K reports, 10-Q reports, and earnings announcements, respectively. Collectively, optimistic and pessimistic tones in financial narratives reflect future performance. A pessimistic tone more strongly reflects future performance and reduces opportunistic incentive to disclose optimistic tone, which can affect stock price, avoid regulatory and investor scrutiny, and ease access from external funding $[4,35]$. This opportunistic behavior only seeks a short-term benefit, and otherwise has a negative effects in terms of reducing manager credibility when it cannot achieve better future performance.

Given managers' opportunistic incentives to disclose positive aspects and ignore the negative aspects in MD\&A reports [36], firms that disclose the negative aspects are likely to be more transparent. In other words, an MD\&A report with more negative aspects, i.e., a pessimistic tone, will have higher disclosure quality; MD\&A reports with more positive aspects, i.e., an optimistic tone, will have lower disclosure quality. This is consistent with empirical evidence that examines the narrative disclosures of earnings announcements [37]. 
Very few studies on the incremental information of textual disclosures have been conducted in the context of developing countries. Aly et al. [12] analyze the tone of annual reports in a developing country, Egypt, and find evidence supporting narrative disclosures' incremental information content. Xiao et al. [38] find that the textual tone in Chinese listed firms' MD\&As conveys managers' expectations about future firm value. Choi et al. [39] offer evidence that textual factors supplement traditional financial variables in predicting corporate credit ratings

\subsection{CSR Disclosure and Greenwashing}

According to [40], both highly and poorly performing firms have incentives to manipulate stakeholders' perception through CSR. Thus, the term "greenwashing" was used to describe the discrepancy between "talk" and "walk" (action) [41]. It even includes unethical and illegal practices $[42,43]$. Considering greenwashing strategies, prior research studies have distinguished two main types, namely attention deflection and decoupling [41,44-46]. Attention deflection practices involve a variety of communication initiatives in disclosure decisions to hype investors' perception. As a result, recent researchers have discussed the idea of CSR as a symbolic strategy, in particular, the use (abuse) of CSR communication as an effective tool of attention deviation to manage organizational audiences' impressions $[44,45]$.

According to [41], greenwashing includes a set of a firm's identity-washing practices to benefit from a "green" image without any concrete action. However, Refs. [47-49] presented greenwashing as the gap between symbolic and substantive actions. The most recurring example of this is chlorofluorocarbon (CFC)-free business. Given its role in ozone depletion, CFC has been legally banned in Indonesia since 2008; however, some companies still advertise their business as CFC-free but, in their operational activity, still use equipment that used CFC [50]. While this may seem harmless, it creates the impression that the product and the brand is more environmentally friendly than it really is [51]. The use of fake labels (a sin we first identified in 2009 and dubbed the "Sin of Worshiping False Labels") is increasing. More than $32 \%$ of "greener" products found in this study carried such a fake label, compared to the $26.8 \%$ in 2009 [46].

\subsection{Pessimistic Tone in Earnings Announcement and CSR Disclosure}

Narrative disclosure has become a new area that management can use to take unethical actions, such as managing external stakeholders' perceptions through the tone used by utilizing information asymmetry. Moreover, this study focuses on one of the tone management practices, namely the use of a pessimistic tone in earnings announcements in the MD\&A report. This may aim to influence the perceptions of external stakeholders following the managerial wishes. On the other hand, according to signaling theory, one of the goals of why management uses a pessimistic tone in earnings announcements is to signal external stakeholders about a decline in managerial performance. The decline in the firm performance will negatively impact the firm's reputation and legitimacy in the future. To cover this, firms carry out CSR disclosures as an effort to give the impression of a transparent firm and divert attention from the firm's financial performance. Research by [52] argues that firms with poor financial reporting are more likely to use social and environmental information as a legitimacy tool to compensate for poor quality financial information.

Consistent with signaling theory, this study suspects that the use of a pessimistic tone in earnings announcements signals that the firm's performance has decreased so that management uses higher CSR disclosures to distract users. Therefore, based on the discussion above, this study tested the first hypothesis as follows:

Hypothesis 1 (H1). Pessimistic tone in earnings announcement is positively related to CSR disclosure. 


\subsection{The Interacting Role of Busy CEO}

Several works of literature have documented the adverse effects of CEO busyness. Research by [21] shows that busy CEOs reduce firm performance. The number of positions held by the CEO can adversely affect the performance of the CEO. In addition, busy CEOs cannot carry out their functions properly due to their limited energy and time $[23,24]$. Another study shows that the CEO's busyness will interfere with the CEO's effectiveness in managing the firm [53] to reduce the firm performance [21] from the decrease in the firm's earnings. In line with the previous research, this study suggests that busy CEOs decrease the firm's performance, reinforcing the use of a pessimistic tone in earnings announcements. Therefore, firms with a busy CEO and pessimistic earnings announcement tone will increase CSR disclosure to gain stakeholder trust and consensus and improve the firm's reputation. With this stated, the second hypothesis of this study is formulated as follows:

Hypothesis 2 (H2). CSR disclosure is higher in firms with a pessimistic tone in earnings announcements and a busy CEO.

\section{Research Design}

\subsection{Variable Definition and Data Sources}

The main variables used in this study are the pessimistic tone in the income statements in MD\&A, busy CEO, and CSR disclosure. CSR disclosure is the dependent variable measured using a CSR disclosure score obtained from the number of items disclosed in the sustainability report divided by the number of items that firms should disclose according to the GRI Index used [54]. This study used two versions of GRI as follows: the GRI G4.0 index, which is valid for 2013-2018 firm-year sustainability reporting, and GRI Standard, which is valid from 2018 firm-year sustainability reporting. Then, several companies chose early voluntary adoption of GRI standard before 2018. The G4 index requires as many as 150 items. On the other hand, the number of items needed to report in GRI standard is divided into two parts as follows: the comprehensive option needs as many as 147 items, while the number of items needed in core options depends on the conditions of each firm, which represents more flexibility than the previous standard. If the firm does not disclose the type of GRI index used, we followed the GRI index in effect in that year. The item reported in GRI shows the triple bottom line (economic, social, and environment aspects). The items which are not required and disclosed in sustainability reporting are immaterial aspects that indirectly affected decision-making by external users.

Additionally, the pessimistic tone is a variable of interest. This variable is measured using a pessimistic tone score obtained from the total pessimistic words according to the list of pessimistic words in Diction 7.0 [55] divided by the total words in the comprehensive income statement in management analysis and discussion [16,56]. Diction 7.0 is a scientific method for determining the tone of a verbal message using a powerful Windows- or Macbased program that searches a passage for five general lexical features as well as thirty-five sub-features (see Table 1). Diction 7.0 conducts its searches via a 10,000-word corpus and up to thirty user created custom dictionaries built with words they have defined (such as topical or negative words) for particular research objectives. The negative words reflect an inverse signal of the positive word to external users related with undoubted financial performance prediction. Meanwhile, Busy CEO is added as an interaction variable which is given a value of 1 if the $\mathrm{CEO}$ has two or more directorship positions outside the firm and 0 if not [21].

Then, referring to previous research [54,57-59], several variables are used in this study. They include the number of firm boards (BOARD), the number of independent commissioners (INDCOM), number of audit committees (AUDCOM), firm size (FSIZE), firm age (FAGE), firm leverage (LEV), operational cash flow (OCF), firm losses (LOSS), and firm performance (ROE). In addition, this study also uses three fixed effect variables to accommodate differences in observational characteristics, namely year fixed effect, industry 
fixed effect, and GRI fixed effect. Furthermore, the operational definition of each variable is listed in Table 2.

Table 1. List of Pessimistic Words Diction 7.0.

\begin{tabular}{ccc}
\hline Blame & Hardship & Denial \\
\hline mean & earthquake & aren't \\
naive & starvation & shouldn't \\
sloppy & tornado & don't \\
stupid & pollution & nor \\
fascist & killers & not \\
blood-thirsty & bankruptcy & nay \\
repugnant & enemies & nothing \\
malicious & vices & nobody \\
bankrupt & infidelity & none \\
rash & despots & \\
morbid & betrayal & \\
embarrassing & injustice & \\
weary & slavery & \\
nervous & exploitation & \\
painful & rebellion & \\
detrimental & grief & \\
cruel & unemployment & \\
illegitimate & died & \\
offensive & apprehension & \\
miserly & error & \\
& cop-outs & \\
& weakness & \\
\hline
\end{tabular}

Our data are pooled as cross-sections using a sample of all listed firms on the IDX and the Global Reporting Initiative (GRI) database for 2016-2019. The sample selection used in this study followed the sample criteria as follows. First, this study excluded firms that are not listed on the GRI. In addition, it excluded missing data in all variables. After setting the criteria sample, we obtained a final sample of 191 observations. The sample selection from this article is summarized in Table 3.

Table 2. Variable Operational Definition.

\begin{tabular}{ccc}
\hline Variables & Proxy & Source \\
\hline CSRD & $\begin{array}{c}\text { CSRIj }=\sum \frac{X_{i j}}{N j} \\
\text { CSRIj: the index of corporate social responsibility } \\
\sum \text { Xij: total items disclosed by the firm } \\
\text { Nj: number of disclosure items according to GRI }\end{array}$ & Sustainability Report \\
\hline TONE & Interested Variable & Annual Report \\
\hline BUSY & Percentage of the number of pessimist terms divided by total word in the \\
comprehensive income statement in MD\&A & Interacting Variable \\
\hline & $\begin{array}{c}\text { Dummy variable, } 1 \text { for CEO who holds two or more other directorships, } \\
\text { and } 0 \text { for CEOs who hold less than two other directorships }\end{array}$ & Bloomberg
\end{tabular}


Table 2. Cont.

\begin{tabular}{|c|c|c|}
\hline Variables & Proxy & Source \\
\hline \multicolumn{3}{|c|}{ Control Variable } \\
\hline BOARD & $\begin{array}{l}\text { Number of members of the board of directors and board of } \\
\text { commissioners in the firm }\end{array}$ & Financial Report \\
\hline INDCOM & Number of members of the independent commissioners & Financial Report \\
\hline AUDCOM & Number of members of the audit committee & Financial Report \\
\hline FSIZE & Natural logarithm of total assets & OSIRIS \\
\hline FAGE & Number of years since the firm was IPO & Annual Report \\
\hline LEV & Total debt divided by total equity & OSIRIS \\
\hline OCF & Net cash flow from operating activities divided by total assets & OSIRIS \\
\hline LOSS & $\begin{array}{c}\text { Dummy variable, value of } 1 \text { if in the previous year the firm received } \\
\text { negative income after tax, and value of } 0 \text { if otherwise }\end{array}$ & OSIRIS \\
\hline $\mathrm{ROE}$ & Net income divided by total equity & OSIRIS \\
\hline \multicolumn{3}{|c|}{ Additional Variable } \\
\hline AVE_TONE & $\begin{array}{c}\text { The average value of the pessimistic tone in earnings announcement by } \\
\text { industry times } 100 .\end{array}$ & Annual Report \\
\hline WORD & Natural logarithm of the total words in the income statements in MD\&A & Annual Report \\
\hline DIFTONE & $\begin{array}{l}\text { The difference between the firm's pessimistic tone and the industry's } \\
\text { average pessimistic tone. }\end{array}$ & Annual Report \\
\hline RW_TONE & $($ TONEt-1 + TONEt-2) $/ 2$ & Annual Report \\
\hline
\end{tabular}

Table 3. Sample selection.

\begin{tabular}{cc}
\hline Description & Firm-Years Observation \\
\hline Firm-Years Observations for 2016-2019 & 2816 Observation \\
Firms that are not listed on the GRI & (2499) Observation \\
Missing data for CSRD variable & $(4)$ Observation \\
Missing data for TONE variable & $(54)$ Observation \\
Missing data for Control (s) & (68) Observation \\
Final sample & 191 Observation \\
\hline
\end{tabular}

\subsection{Methodology}

We used the ordinary least squares (OLS) regression to examine whether pessimistic tone can explain any differences in CSR disclosure among the listed companies and consider busy CEO as interacting variable [60]. For all regression models, we include industry, GRI, and year fixed effects. A previous study also used OLS to examine the relationship between CSR disclosure and the explanatory variable [54,61]. The first empirical model was used to answer Hypothesis 1. In our prediction, the pessimist tone in the MD\&A income statement is positively and significantly related to CSR disclosure.

$$
\begin{aligned}
& \text { CSRD }_{i, t}=\beta_{0}+\beta_{1} \text { TONE }_{i, t}+\beta_{2} \text { BUSY }_{i, t}+\beta_{3} \text { BOARD }_{i, t}+\beta_{4} \text { INDCOM }_{i, t}+\beta_{5} \text { AUDCOM }_{i, t}+\beta_{6} \text { FSIZE }_{i, t}+\beta_{7} \\
& \text { FAGE }_{i, t}+\beta_{8} \text { LEV }_{i, t}+\beta_{9} \text { OCF }_{i, t}+\beta_{10} \text { LOSS }_{i, t}+\beta_{11} \text { ROE }_{i, t}+\beta_{12} \text { YEAR }_{i, t}+\beta_{13} \text { INDUSTRY }_{i, t}+\beta_{14} \text { GRI }_{i, t}+\varepsilon_{i, t}
\end{aligned}
$$

Moreover, a second empirical model was used to answer Hypothesis 2. We predicted that the presence of a busy CEO strengthens the relationship between pessimistic tone in earnings announcement and CSR disclosure.

$$
\begin{gathered}
\text { CSRD }_{i, t}=\beta_{0}+\beta_{1} \text { TONE*BUSY }_{i, t}+\beta_{2} \text { TONE }_{i, t}+\beta_{3} \text { BUSY }_{i, t}+\beta_{4} \text { BOARD }_{i, t}+\beta_{5} \text { INDCOM }_{i, t}+\beta_{6} \text { AUDCOM }_{i, t}+\beta_{7} \\
\text { FSIZE }_{i, t}+\beta_{8} \text { FAGE }_{i, t}+\beta_{9} \text { LEV }_{i, t}+\beta_{10} \text { OCF }_{i, t}+\beta_{11} \text { LOSS }_{i, t}+\beta_{12} \text { ROE }_{i, t}+\beta_{13} \text { YEAR }_{i, t}+\beta_{14} \text { INDUSTRY }_{i, t}+\beta_{15} \\
\text { GRI }_{i, t}+\varepsilon_{i, t}
\end{gathered}
$$

This study used the Heckman two-stage model for robustness analysis aligned with previous study $[54,61,62]$. We used this model because it is very effective in dealing with potential endogeneity concerns in this study. To perform this analysis, an instrument 
variable is required, which must be related to the suspected endogenous variable but not associated with the error term of the dependent variable [63]. Thus, in this study, the instrument variable must be related to pessimistic tone but not related to CSR disclosure. In addition, it also added additional analysis to support the main test results.

\section{Results and Discussion}

\subsection{Descriptive Statistics and Univariate Analysis}

This study used a sample of 191 observations from all listed companies on the IDX and the Global Reporting Initiative (GRI) database for 2016-2019. The distribution of the sample used in this study is presented in Table 4. Sample distribution is presented based on industry code using SIC. Thus, our sample is divided into eight sectors. Then, we divided our sample into firms with a pessimistic tone and firms with no pessimistic tone. We categorized firms as having a pessimistic tone if they had a positive pessimistic score. We found that the lowest number of samples for companies that used a pessimistic tone in this study are in the agriculture, forestry, fisheries (SIC 0), and service industries (SIC 7), with as many as three observations. On the other hand, the highest number of samples for firms that used a pessimistic tone in this study is industry (SIC 1), with as many as 21 observations.

Table 4. Sample Distribution.

\begin{tabular}{|c|c|c|c|c|c|c|}
\hline \multirow{2}{*}{ Industry } & \multicolumn{2}{|c|}{ Pessimistic Tone } & \multicolumn{2}{|c|}{ Non-Pessimistic Tone } & \multicolumn{2}{|c|}{ Total } \\
\hline & $\mathbf{N}$ & $\%$ & $\mathbf{N}$ & $\%$ & $\mathbf{N}$ & $\%$ \\
\hline (SIC 0) Agriculture, Forestry, and Fisheries & 3 & 16 & 16 & 84 & 19 & 100 \\
\hline (SIC 1) Mining & 21 & 38 & 34 & 62 & 55 & 100 \\
\hline (SIC 2) Construction & 14 & 38 & 23 & 62 & 37 & 100 \\
\hline (SIC 3) Manufacturing & 5 & 25 & 15 & 75 & 20 & 100 \\
\hline $\begin{array}{c}\text { (SIC 4) Transportation, Communication, } \\
\text { and Utilities }\end{array}$ & 13 & 50 & 13 & 50 & 26 & 100 \\
\hline (SIC 5) Wholesale and Retail Trade & 7 & 54 & 6 & 46 & 13 & 100 \\
\hline (SIC 6) Finance, Insurance, and Real Estate & 5 & 36 & 9 & 64 & 14 & 100 \\
\hline (SIC 7) Services & 3 & 43 & 4 & 47 & 7 & 100 \\
\hline Total & 71 & 37 & 120 & 63 & 191 & 100 \\
\hline
\end{tabular}

The descriptive statistics in this study are shown in Table 5. CSRD values range from 0 to 1 . The lowest CSRD value is zero in the sample we use, and the highest CSRD value is 0.95 . In addition, the average value of CSR is 0.405 . It means that the average firm discloses CSR by $40.5 \%$ of the total disclosure items listed in the GRI index used.

Furthermore, the use of a pessimistic tone in the income statements in MD\&A is still rarely used. Our sample notes that the mean use of a pessimistic tone is $8.2 \%$, the mean busy CEO is 0.476 , and the mean number of boards is 11.366 . In addition, the mean number of independent commissioners is 2.141, while the mean number of audit committees is 3.141. In addition, our sample has a mean firm size of 30.422, a mean firm age of 16.188, and a mean loss rate of 0.173 . In addition, descriptive statistics also show that the firm's mean leverage is 1.615 , the mean operating cash flow is 0.079 , and the mean return on equity is 0.113. Then, we include average tone, total word, differential tone, and rolling window tone. The mean of average tone is 8.155 , mean total word is 6.388 , mean differential tone is -0.000 , and mean rolling window tone is 0.081 .

Table 6 shows the Pearson correlation test. Again, all continuous variables have been winsorized at $1 \%$ and $99 \%$ to alleviate potential problems with outliers. The results of the Pearson correlation test show that the pessimistic tone is positively but not significantly related to CSRD. Furthermore, busy CEO is negatively and significantly related to CSRD. These results indicate that the higher the CEO's busyness, the lower the level of CSR disclosure. 
Table 5. Descriptive Statistics.

\begin{tabular}{ccccc}
\hline Variable $^{1}$ & Mean & Median & Minimum & Maximum \\
\hline CSRD & 0.405 & 0.388 & 0.000 & 0.950 \\
TONE & 0.082 & 0.000 & 0.000 & 0.595 \\
BUSY & 0.476 & 0.000 & 0.000 & 1.000 \\
BOARD & 11.366 & 11.000 & 5.000 & 21.000 \\
INDCOM & 2.141 & 2.000 & 1.000 & 5.000 \\
AUDCOM & 3.141 & 3.000 & 1.000 & 6.000 \\
FSIZE & 30.422 & 30.529 & 25.914 & 33.474 \\
FAGE & 16.188 & 14.000 & 1.000 & 40.000 \\
LEV & 1.615 & 1.216 & -2.114 & 11.909 \\
OCF & 0.079 & 0.070 & -0.234 & 0.531 \\
LOSS & 0.173 & 0.000 & 0.000 & 1.000 \\
ROE & 0.113 & 0.088 & -1.621 & 1.400 \\
AVE_TONE & 8.155 & 9.891 & 0.000 & 15.310 \\
WORD & 6.388 & 6.372 & 4.990 & 8.208 \\
DIFTONE & -0.000 & -0.050 & -0.153 & 0.496 \\
RW_TONE & 0.081 & 0.038 & 0.000 & 0.332 \\
\hline
\end{tabular}

${ }^{1}$ This table reports the descriptive statistics of 191 firm-year observations. This analysis uses winsorized data at 1 and $99 \%$. Descriptive statistics indicator includes mean, median, minimum, and maximum value.

Moreover, LOSS is also negatively and significantly associated with CSRD. These results indicate that companies that experience losses are less likely to disclose CSR. In addition, AUDCOM and FSIZE are positively and significantly related to CSRD.

Table 6. Pearson Correlation.

\begin{tabular}{|c|c|c|c|c|c|c|c|}
\hline & Variable $^{1}$ & (1) & (2) & (3) & (4) & (5) & (6) \\
\hline (1) & CSRD & 1.000 & & & & & \\
\hline$(2)$ & TONE & $\begin{array}{c}0.071 \\
(0.332)\end{array}$ & 1.000 & & & & \\
\hline (3) & BUSY & $\begin{array}{c}-0.134 \text { * } \\
(0.065)\end{array}$ & $\begin{array}{l}-0.090 \\
(0.214)\end{array}$ & 1.000 & & & \\
\hline (4) & BOARD & $\begin{array}{c}0.075 \\
(0.301)\end{array}$ & $\begin{array}{c}-0.132 * \\
(0.069)\end{array}$ & $\begin{array}{c}0.153 * * \\
(0.034)\end{array}$ & 1.000 & & \\
\hline (5) & INDCOM & $\begin{array}{c}0.032 \\
(0.665)\end{array}$ & $\begin{array}{l}-0.087 \\
(0.231)\end{array}$ & $\begin{array}{l}0.133 * \\
(0.067)\end{array}$ & $\begin{array}{c}0.622^{* * *} \\
(0.000)\end{array}$ & 1.000 & \\
\hline (6) & AUDCOM & $\begin{array}{l}0.139 * \\
(0.056)\end{array}$ & $\begin{array}{c}-0.030 \\
(0.679)\end{array}$ & $\begin{array}{l}-0.114 \\
(0.115)\end{array}$ & $\begin{array}{l}0.126 * \\
(0.082)\end{array}$ & $\begin{array}{c}0.069 \\
(0.346)\end{array}$ & 1.000 \\
\hline (7) & FSIZE & $\begin{array}{l}0.140 * \\
(0.054)\end{array}$ & $\begin{array}{c}0.031 \\
(0.673)\end{array}$ & $\begin{array}{c}0.181 * * \\
(0.012)\end{array}$ & $\begin{array}{c}0.512^{* * *} \\
(0.000)\end{array}$ & $\begin{array}{c}0.322 * * * \\
(0.000)\end{array}$ & $\begin{array}{c}0.198^{* * *} \\
(0.006)\end{array}$ \\
\hline (8) & FAGE & $\begin{array}{c}0.062 \\
(0.393)\end{array}$ & $\begin{array}{c}0.021 \\
(0.769)\end{array}$ & $\begin{array}{c}0.119 \\
(0.101)\end{array}$ & $\begin{array}{c}0.213^{* * *} \\
(0.003)\end{array}$ & $\begin{array}{c}0.284^{* * *} \\
(0.000)\end{array}$ & $\begin{array}{l}-0.075 \\
(0.304)\end{array}$ \\
\hline (9) & LEV & $\begin{array}{c}-0.023 \\
(0.754)\end{array}$ & $\begin{array}{c}0.050 \\
(0.488)\end{array}$ & $\begin{array}{l}-0.053 \\
(0.466)\end{array}$ & $\begin{array}{c}-0.032 \\
(0.659)\end{array}$ & $\begin{array}{c}0.003 \\
(0.967)\end{array}$ & $\begin{array}{c}0.057 \\
(0.437)\end{array}$ \\
\hline (10) & OCF & $\begin{array}{c}-0.015 \\
(0.832)\end{array}$ & $\begin{array}{c}0.032 \\
(0.664)\end{array}$ & $\begin{array}{l}-0.042 \\
(0.562)\end{array}$ & $\begin{array}{l}0.141 * \\
(0.053)\end{array}$ & $\begin{array}{c}0.229 * * * \\
(0.001)\end{array}$ & $\begin{array}{c}-0.114 \\
(0.117)\end{array}$ \\
\hline (11) & LOSS & $\begin{array}{c}-0.128 * \\
(0.078)\end{array}$ & $\begin{array}{l}-0.017 \\
(0.816)\end{array}$ & $\begin{array}{c}0.008 \\
(0.916)\end{array}$ & $\begin{array}{c}-0.071 \\
(0.328)\end{array}$ & $\begin{array}{l}-0.010 \\
(0.885)\end{array}$ & $\begin{array}{l}-0.017 \\
(0.814)\end{array}$ \\
\hline (12) & $\mathrm{ROE}$ & $\begin{array}{c}0.013 \\
(0.853)\end{array}$ & $\begin{array}{l}-0.041 \\
(0.575)\end{array}$ & $\begin{array}{c}-0.054 \\
(0.462)\end{array}$ & $\begin{array}{c}0.185 * * \\
(0.010)\end{array}$ & $\begin{array}{c}0.273^{* * *} \\
(0.000)\end{array}$ & $\begin{array}{l}-0.119 \\
(0.102)\end{array}$ \\
\hline
\end{tabular}


Table 6. Cont.

\begin{tabular}{cccccccc}
\hline & & $\mathbf{( 7 )}$ & $\mathbf{( 8 )}$ & $\mathbf{( 9 )}$ & $\mathbf{( 1 0 )}$ & $\mathbf{( 1 1 )}$ & $\mathbf{( 1 2 )}$ \\
\hline$(7)$ & FSIZE & 1.000 & & & & & \\
\hline$(8)$ & FAGE & 0.113 & 1.000 & & & \\
& & $(0.119)$ & & & & \\
\hline$(9)$ & LEV & 0.092 & -0.041 & 1.000 & & & \\
& & $(0.208)$ & $(0.576)$ & & & & \\
\hline$(10)$ & OCF & -0.082 & $0.358^{* * *}$ & -0.059 & 1.000 & & \\
& & $(0.260)$ & $(0.000)$ & $(0.414)$ & & & \\
\hline$(11)$ & LOSS & $-0.227^{* * *}$ & -0.069 & $0.138^{*}$ & $-0.141^{*}$ & 1.000 & \\
& & $(0.002)$ & $(0.344)$ & $(0.056)$ & $(0.053)$ & & \\
\hline$(12)$ & ROE & 0.033 & $0.339^{* * *}$ & $-0.174^{* *}$ & $0.519 * * *$ & $-0.385^{* * *}$ & 1.000 \\
& & $(0.654)$ & $(0.000)$ & $(0.016)$ & $(0.000)$ & $(0.000)$ & \\
\hline
\end{tabular}

${ }^{1}$ This table shows Pearson Correlation analysis result on 191 firm-year observations for this study. This analysis uses winsorized data at 1 and $99 \%$. $p$-value in parentheses ${ }^{*} p<0.1,{ }^{* *} p<0.05,{ }^{* * *} p<0.01$.

\subsection{Pessimistic Tone in Earnings Announcement and CSR Disclosure}

Table 7 presents the results of the OLS test related to the relationship between pessimistic tone in earnings announcement and CSR disclosure. Specification (1) shows the relationship between control variables and CSR disclosure. Then, specification (2) shows that the pessimistic tone in earnings announcements is positively and significantly related to CSR disclosure with a coefficient value of 0.150 ( $t$ value $=2.23$ ) at a significance level of $5 \%$. These results indicate that firms that use a pessimistic tone in earnings announcements make higher CSR disclosures. Thus, hypothesis 1 is accepted.

This result is consistent with [36,37] that MD\&A reports with more negative aspects, i.e., a pessimistic tone, will have higher transparency and bring symmetry information. The more transparent and symmetry information means the higher expectation from an external party. Managers use a pessimistic tone in order to signal an external party about the possibility of underperforming due to economic and non-economic factors reported [16]. As a consequence, CSR disclosure is an effective tool to strengthen corporate image [18], manage reputation risk [19], and reduce potential legitimacy gaps [17]. Managers disclose CSR more to distract users when firm management uses a pessimistic tone in the income statements disclosure in MD\&A.

This finding also supports previous research about the importance of transparency to reduce asymmetry information [1]. CSR disclosure is used to give the impression of a transparent firm (reputation) and distract users from the firm's financial performance when a company states a pessimistic tone in earnings announcement [17]. Additionally, using negative language in MD\&A reports attracts investor attention, because their signal means that every decision made by the manager considers the worst case.

\subsection{Interaction between Pessimistic Tone in Earnings Announcement and Busy CEO on CSR Disclosure}

Table 8 presents the results of testing the interaction between the tone of pessimistic earnings announcements and busy CEOs on CSR disclosure. The results show a positive and significant relationship with a coefficient of $0.286(t$ value $=1.97)$ at a significance level of $10 \%$. These results indicate that CSR disclosure is higher in firms with a pessimistic tone in earnings announcements and a busy CEO. Thus, Hypothesis 2 is accepted. The use of a pessimistic tone in earnings announcements can signal that the firm is experiencing a decline in performance, one of which may be due to a busy CEO. Previous literature stated that busy CEOs would not carry out their functions properly due to their limited energy and time [23,24]. Therefore, it reduces the firm's performance [64-66]. As a result, companies use CSR disclosures to distract users. This state is in line with the function of CSR, namely to increase social legitimacy [67,68], gain stakeholder trust and consensus [69], and improve the firm's reputation [70]. 
Table 7. Pessimistic Tone in Earnings Announcement and CSR Disclosure.

\begin{tabular}{|c|c|c|c|c|}
\hline Variable $^{1}$ & CSRD $^{2}$ & CSRD $^{3}$ & $\operatorname{CSRD}^{4}$ & CSRD $^{5}$ \\
\hline TONE & & $\begin{array}{c}0.150 * * \\
(2.23)\end{array}$ & & $\begin{array}{c}0.131 \text { * } \\
(1.87)\end{array}$ \\
\hline BUSY & & & $\begin{array}{c}-0.041 * * \\
(-2.10)\end{array}$ & $\begin{array}{c}-0.036 \text { * } \\
(-1.78)\end{array}$ \\
\hline BOARD & $\begin{array}{l}0.008 \\
(1.56)\end{array}$ & $\begin{array}{c}0.009 * \\
(1.76)\end{array}$ & $\begin{array}{c}0.009 * \\
(1.75)\end{array}$ & $\begin{array}{c}0.010 * \\
(1.91)\end{array}$ \\
\hline INDCOM & $\begin{array}{l}-0.010 \\
(-0.63)\end{array}$ & $\begin{array}{l}-0.010 \\
(-0.64)\end{array}$ & $\begin{array}{l}-0.006 \\
(-0.39)\end{array}$ & $\begin{array}{l}-0.006 \\
(-0.43)\end{array}$ \\
\hline AUDCOM & $\begin{array}{l}0.020 \\
(0.98)\end{array}$ & $\begin{array}{l}0.023 \\
(1.13)\end{array}$ & $\begin{array}{l}0.014 \\
(0.74)\end{array}$ & $\begin{array}{l}0.017 \\
(0.91)\end{array}$ \\
\hline FSIZE & $\begin{array}{l}-0.004 \\
(-0.29)\end{array}$ & $\begin{array}{l}-0.005 \\
(-0.41)\end{array}$ & $\begin{array}{l}-0.002 \\
(-0.13)\end{array}$ & $\begin{array}{l}-0.003 \\
(-0.26)\end{array}$ \\
\hline FAGE & $\begin{array}{c}0.003^{* *} \\
(2.51)\end{array}$ & $\begin{array}{c}0.003^{* *} \\
(2.52)\end{array}$ & $\begin{array}{c}0.003^{* * *} \\
(2.68)\end{array}$ & $\begin{array}{c}0.003^{* * *} \\
(2.66)\end{array}$ \\
\hline LEV & $\begin{array}{l}-0.005 \\
(-1.07)\end{array}$ & $\begin{array}{l}-0.005 \\
(-1.09)\end{array}$ & $\begin{array}{l}-0.006 \\
(-1.36)\end{array}$ & $\begin{array}{l}-0.006 \\
(-1.34)\end{array}$ \\
\hline OCF & $\begin{array}{l}-0.097 \\
(-0.85)\end{array}$ & $\begin{array}{l}-0.116 \\
(-0.98) \\
\end{array}$ & $\begin{array}{l}-0.111 \\
(-0.98)\end{array}$ & $\begin{array}{l}-0.126 \\
(-1.08)\end{array}$ \\
\hline LOSS & $\begin{array}{l}-0.047^{*} \\
(-1.70)\end{array}$ & $\begin{array}{l}-0.043 \\
(-1.59)\end{array}$ & $\begin{array}{c}-0.046 * \\
(-1.77)\end{array}$ & $\begin{array}{c}-0.043 \text { * } \\
(-1.65)\end{array}$ \\
\hline $\mathrm{ROE}$ & $\begin{array}{l}0.032 \\
(1.47)\end{array}$ & $\begin{array}{l}0.036 \\
(1.60)\end{array}$ & $\begin{array}{l}0.024 \\
(1.06)\end{array}$ & $\begin{array}{l}0.029 \\
(1.24)\end{array}$ \\
\hline _CONS & $\begin{array}{l}0.355 \\
(0.99)\end{array}$ & $\begin{array}{l}0.382 \\
(1.06)\end{array}$ & $\begin{array}{l}0.316 \\
(0.88)\end{array}$ & $\begin{array}{l}0.344 \\
(0.95)\end{array}$ \\
\hline YEAR FE & Yes & Yes & Yes & Yes \\
\hline INDUSTRY FE & Yes & Yes & Yes & Yes \\
\hline GRI FE & Yes & Yes & Yes & Yes \\
\hline $\mathrm{R} 2$ & 0.602 & 0.612 & 0.612 & 0.619 \\
\hline Adjusted_R2 & 0.550 & 0.559 & 0.558 & 0.564 \\
\hline$N$ & 191 & 191 & 191 & 191 \\
\hline
\end{tabular}

${ }^{1}$ This table reports the main regression analysis of 191 firm-year observations for this study. This analysis uses winsorized data at 1 and $99 \%$. $p$-value in parentheses ${ }^{*} p<0.1, * * p<0.05, * * *<0.01 .{ }^{2}$ This column only includes control variables with year, industry, and GRI FE in the regression model. ${ }^{3,4}$ This column includes interested variable and controls variables with year, industry, and GRI FE in the regression model. ${ }^{5}$ This column includes interested and control variables with year, industry, and GRI FE in the regression model.

\subsection{Robustness Analysis}

This study used the Heckman two-stage as a robustness test to strengthen the main findings and overcome the problem of endogeneity in the relationship between pessimistic tone in earnings announcement and CSR disclosure. The results of the two-stage Heckman test are presented in Table 9. The two-stage Heckman test required instrument variables, namely variables related to suspected endogenous variables but not related to the error term of the dependent variable [71]. We used two instrument variables in this study, namely total words (WORD) and industry average (AVE_TONE). WORD is measured using the natural logarithm of the total words in the income statements in MD\&A. In contrast, AVE_TONE is measured using the average value of the pessimistic tone in earnings announcement by industry times 100 . Referring to the research conducted by [72,73], in the first stage, this study examined the relationship between instrument variables WORD, AVE_TONE, and the pessimistic tone in earnings announcements using a dummy variable. The test 
results show that WORD and AVE_TONE are positively and significantly related to the pessimistic tone in earnings announcements, respectively.

Table 8. Interaction of Pessimistic Tone in Earnings Announcement and Busy CEO.

\begin{tabular}{|c|c|}
\hline Variable $^{1}$ & CSRD $^{2}$ \\
\hline \multirow[t]{2}{*}{ TONE_BUSY } & $0.286^{*}$ \\
\hline & (1.97) \\
\hline \multirow[t]{2}{*}{ TONE } & 0.020 \\
\hline & $(0.25)$ \\
\hline \multirow[t]{2}{*}{ BUSY } & $-0.054^{* *}$ \\
\hline & $(-2.47)$ \\
\hline \multirow[t]{2}{*}{ BOARD } & $0.009 *$ \\
\hline & (1.86) \\
\hline \multirow[t]{2}{*}{ INDCOM } & -0.004 \\
\hline & $(-0.26)$ \\
\hline \multirow[t]{2}{*}{ AUDCOM } & 0.016 \\
\hline & $(0.87)$ \\
\hline \multirow[t]{2}{*}{ FSIZE } & -0.006 \\
\hline & $(-0.46)$ \\
\hline \multirow[t]{2}{*}{ FAGE } & $0.003^{* *}$ \\
\hline & (2.43) \\
\hline \multirow[t]{2}{*}{ LEV } & -0.007 \\
\hline & $(-1.52)$ \\
\hline \multirow[t]{2}{*}{ OCF } & -0.127 \\
\hline & $(-1.12)$ \\
\hline \multirow[t]{2}{*}{ LOSS } & $-0.046^{*}$ \\
\hline & $(-1.81)$ \\
\hline \multirow[t]{2}{*}{$\mathrm{ROE}$} & 0.035 \\
\hline & (1.44) \\
\hline \multirow[t]{2}{*}{ _CONS } & 0.440 \\
\hline & (1.24) \\
\hline YEAR FE & Yes \\
\hline INDUSTRY FE & Yes \\
\hline GRI FE & Yes \\
\hline $\mathrm{R} 2$ & 0.627 \\
\hline ADJUSTED_R2 & 0.571 \\
\hline$N$ & 191 \\
\hline
\end{tabular}

${ }^{1}$ This table reports the main regression analysis of 191 firm-year observations for this study. This analysis uses winsorized data at 1 and $99 \%$. $p$-value in parentheses ${ }^{*} p<0.1,{ }^{* *} p<0.05 ;{ }^{2}$ This column includes interacting variable and controls variables with year, industry, and GRI FE in the regression model. 
Table 9. Heckman Two-Stage Analysis.

\begin{tabular}{|c|c|c|c|}
\hline \multirow[b]{2}{*}{ Variable $^{1}$} & \multirow{2}{*}{$\begin{array}{c}\text { First Stage } \\
\text { TONE }^{2}\end{array}$} & \multicolumn{2}{|c|}{ Second Stage } \\
\hline & & $\operatorname{CSRD}^{3}$ & $\operatorname{CSRD}^{4}$ \\
\hline \multirow[t]{2}{*}{ WORD } & $0.820^{* * *}$ & & \\
\hline & $(4.03)$ & & \\
\hline \multirow[t]{2}{*}{ AVE_TONE } & $1.931^{* * *}$ & & \\
\hline & (7.47) & & \\
\hline \multirow[t]{2}{*}{ TONE_BUSY } & & & 0.285 * \\
\hline & & & $(1.95)$ \\
\hline \multirow[t]{2}{*}{ TONE } & & $0.131 *$ & 0.020 \\
\hline & & (1.87) & $(0.25)$ \\
\hline \multirow[t]{2}{*}{ BUSY } & $-0.600^{* * *}$ & -0.033 & -0.052 * \\
\hline & $(-2.62)$ & $(-1.38)$ & $(-1.97)$ \\
\hline \multirow[t]{2}{*}{ BOARD } & -0.050 & $0.010 *$ & $0.010 *$ \\
\hline & $(-1.02)$ & (1.84) & $(1.80)$ \\
\hline \multirow[t]{2}{*}{ INDCOM } & -0.042 & -0.006 & -0.004 \\
\hline & $(-0.24)$ & $(-0.42)$ & $(-0.25)$ \\
\hline \multirow[t]{2}{*}{ AUDCOM } & $-0.537^{* * *}$ & 0.019 & 0.018 \\
\hline & $(-2.61)$ & $(0.95)$ & $(0.89)$ \\
\hline \multirow[t]{2}{*}{ FSIZE } & 0.177 & -0.005 & -0.007 \\
\hline & (1.49) & $(-0.31)$ & $(-0.48)$ \\
\hline \multirow[t]{2}{*}{ FAGE } & -0.011 & $0.003^{* * *}$ & 0.003 ** \\
\hline & $(-0.83)$ & $(2.70)$ & $(2.40)$ \\
\hline \multirow[t]{2}{*}{ LEV } & -0.008 & -0.006 & -0.007 \\
\hline & $(-0.10)$ & $(-1.31)$ & $(-1.50)$ \\
\hline \multirow[t]{2}{*}{ OCF } & $2.239 *$ & -0.139 & -0.138 \\
\hline & $(1.69)$ & $(-1.06)$ & $(-1.07)$ \\
\hline \multirow[t]{2}{*}{ LOSS } & -0.319 & -0.042 & $-0.045^{*}$ \\
\hline & $(-0.94)$ & $(-1.56)$ & $(-1.71)$ \\
\hline \multirow[t]{2}{*}{ ROE } & -0.101 & 0.030 & 0.036 \\
\hline & $(-0.27)$ & $(1.26)$ & $(1.46)$ \\
\hline \multirow[t]{2}{*}{ MILLS } & & -0.006 & -0.005 \\
\hline & & $(-0.21)$ & $(-0.18)$ \\
\hline \multirow[t]{2}{*}{ _CONS } & $-13.691 * * *$ & 0.381 & 0.470 \\
\hline & $(-3.75)$ & $(0.91)$ & (1.15) \\
\hline YEAR FE & Yes & Yes & Yes \\
\hline INDUSTRY FE & Yes & Yes & Yes \\
\hline GRI FE & Yes & Yes & Yes \\
\hline R2 & 0.257 & 0.619 & 0.627 \\
\hline Adjusted_R2 & & 0.562 & 0.568 \\
\hline$N$ & 191 & 191 & 191 \\
\hline
\end{tabular}

${ }^{1}$ This table reports two-stage Heckman regression using 191 firm-year observations for this study. This analysis uses winsorized data at 1 and $99 \%$. $p$-value in parentheses ${ }^{*} p<0.1,{ }^{* *} p<0.05,{ }^{* * *} p<0.01{ }^{2}$ This column reports first-stage Heckman regression using WORD and AVE_TONE as instrumental variable. Dummy TONE as dependent variable. ${ }^{3}$ This column reports second-stage Heckman regression using 191 firm-year observations to analyze interested variables. ${ }^{4}$ This column reports second-stage Heckman regression using 191 firm-year observations to analyze interacting variables.

Furthermore, this study tested Hypothesis 1 and Hypothesis 2 in the second stage. First, specification (1) shows the relationship between pessimistic tone in earnings an- 
nouncement and CSR disclosure. Consistent with Table 7, the pessimistic tone in earnings announcements is positively and significantly related to CSR disclosure. Second, specification (2) shows the relationship between the pessimistic tone in earnings announcements, busy CEO, and CSR disclosure. The results are consistent with Table 8, that busy CEOs strengthen the relationship between the pessimistic tone in earnings announcements and CSR disclosures. In addition, the MILLS ratio shows insignificant results. It shows that the relationship between pessimistic tone in earnings announcement and CSR disclosure is free from endogeneity problems.

\subsection{Additional Analysis}

This study undertook additional analysis to deepen the contributions of the relationship between the pessimistic tone in earnings announcements and CSR disclosure. We present two different scenarios. First, this study used a differential tone measured by the difference between the firm's pessimistic tone and the industry's average pessimistic tone. The test results can be seen in Table 10, which explains that DIFTONE has a positive and significant relationship with CSR with a coefficient of 0.131 ( $t$ value $=1.87$ ) at a significance level of $10 \%$. It means that firms that use a pessimistic tone in earnings announcements above the industry average have higher CSR disclosures. This result indicates that firms that use a pessimistic tone higher than the industry average have more substantial pressure to increase CSR disclosure to maintain trust and legitimacy from users. In addition, the presence of a busy CEO reinforces this pressure. These results are consistent with our main findings in Tables 7 and 8.

Table 10. Differential Pessimistic Tone.

\begin{tabular}{|c|c|c|}
\hline Variable $^{1}$ & CSRD $^{2}$ & CSRD $^{3}$ \\
\hline \multirow[t]{2}{*}{ DIFTONE_BUSY } & & $0.270 *$ \\
\hline & & $(1.80)$ \\
\hline \multirow[t]{2}{*}{ DIFTONE } & $0.131 *$ & 0.028 \\
\hline & $(1.87)$ & $(0.36)$ \\
\hline \multirow[t]{2}{*}{ BUSY } & $-0.036^{*}$ & -0.032 \\
\hline & $(-1.78)$ & $(-1.61)$ \\
\hline \multirow[t]{2}{*}{ BOARD } & $0.010 *$ & $0.009 *$ \\
\hline & $(1.91)$ & $(1.77)$ \\
\hline \multirow[t]{2}{*}{ INDCOM } & -0.006 & -0.004 \\
\hline & $(-0.43)$ & $(-0.25)$ \\
\hline \multirow[t]{2}{*}{ AUDCOM } & 0.017 & 0.016 \\
\hline & $(0.91)$ & $(0.84)$ \\
\hline \multirow[t]{2}{*}{ FSIZE } & -0.003 & -0.005 \\
\hline & $(-0.26)$ & $(-0.43)$ \\
\hline \multirow[t]{2}{*}{ FAGE } & $0.003^{* * *}$ & $0.003 * *$ \\
\hline & $(2.66)$ & $(2.45)$ \\
\hline \multirow[t]{2}{*}{ LEV } & -0.006 & -0.007 \\
\hline & $(-1.34)$ & $(-1.47)$ \\
\hline \multirow[t]{2}{*}{ OCF } & -0.126 & -0.126 \\
\hline & $(-1.08)$ & $(-1.10)$ \\
\hline \multirow[t]{2}{*}{ LOSS } & $-0.043 *$ & $-0.046^{*}$ \\
\hline & $(-1.65)$ & $(-1.79)$ \\
\hline
\end{tabular}


Table 10. Cont.

\begin{tabular}{ccc}
\hline Variable $^{\mathbf{1}}$ & CSRD $^{\mathbf{2}}$ & CSRD $^{\mathbf{3}}$ \\
\hline ROE & 0.029 & 0.035 \\
\hline _CONS & $(1.24)$ & $(1.44)$ \\
\hline & 0.348 & 0.425 \\
\hline YEAR FE & $(0.96)$ & $(1.19)$ \\
\hline INDUSTRY FE & Yes & Yes \\
\hline GRI FE & Yes & Yes \\
\hline R2 & Yes & Yes \\
\hline Adjusted_R2 & 0.619 & 0.626 \\
\hline$N$ & 0.564 & 0.569 \\
\hline
\end{tabular}

${ }^{1}$ This table reports additional analysis using differential tone using 191 firm-year observations. This analysis uses winsorized data at 1 and $99 \% p$-value in parentheses ${ }^{*} p<0.1,{ }^{* *} p<0.05,{ }^{* * *} p<0.01 .{ }^{2}$ This column uses DIFTONE as independent variable, measured by the difference between the firm's pessimistic tone and the industry's average pessimistic tone. ${ }^{3}$ This column shows interaction between DIFTONE and BUSY using 191 firm-year observations.

In the same way, our second additional analysis considers the effect of the previous year's pessimistic tone on CSR disclosure. The reason is that the higher CSR disclosure in the current year may be due to a pessimistic tone in the previous year rather than in the same year. Therefore, we examined a pessimistic tone in previous years by using a rolling window and observing its relationship with CSR disclosure in the current year. Referring to the research by [62], this study measured the rolling window tone of pessimism using the formula RW_TONE $=($ TONEt $-1+$ TONEt-2) $/ 2$. Our test results are shown in Table 11. The results show that, even though it is measured using the tone of the previous year's earnings announcements, the relationship between the pessimistic tone in earnings announcements and CSR disclosures remains positive and significant. These results confirm our main finding that a pessimistic tone in earnings announcements is related to higher CSR disclosures.

Table 11. Rolling-Window Regression Analysis.

\begin{tabular}{cc}
\hline Variable $^{1}$ & CSRD $^{2}$ \\
\hline RW_TONE & $0.339^{*}$ \\
\hline & $(1.70)$ \\
\hline BUSY & -0.044 \\
\hline BOARD & $(-1.15)$ \\
\hline & -0.003 \\
\hline INDCOM & $(-0.32)$ \\
\hline AUDCOM & 0.022 \\
\hline FSIZE & $(0.81)$ \\
\hline & $0.094{ }^{*}$ \\
\hline FAGE & $(1.91)$ \\
\hline & 0.005 \\
\hline
\end{tabular}


Table 11. Cont.

\begin{tabular}{cc}
\hline Variable $^{1}$ & CSRD $^{2}$ \\
\hline LEV & 0.008 \\
\hline OCF & $(0.53)$ \\
\hline & 0.212 \\
\hline LOSS & $(0.77)$ \\
\hline ROE & -0.021 \\
\hline CONS & $(-0.36)$ \\
\hline YEAR FE & -0.122 \\
\hline INDUSTRY FE & $(-0.99)$ \\
\hline GRI FE & -0.362 \\
\hline R2 & $(-0.71)$ \\
\hline Adjusted_R2 & Yes \\
\hline$N$ & Yes \\
\hline
\end{tabular}

${ }^{1}$ This table reports additional analysis using a rolling window of TONE between $\mathrm{t}-1$ and $\mathrm{t}-2$. This analysis uses winsorized data at 1 and $99 \%$. $p$-value in parentheses ${ }^{*} p<0.1 ;^{2}$ This column uses RW_TONE as independent variable, measured by (TONEt-1 + TONEt-2)/2. This analysis uses only 64 firm-year observations, and, as a result, we only consider 2018-2019 period due to data limitation of TONEt-2.

\section{Conclusions}

This study investigates the relationship between the pessimistic tone in earnings announcements and CSR disclosure and how busy CEOs play a role in this relationship. This study uses a sample of all listed companies on the Indonesia Stock Exchange and the Global Reporting Initiative database during 2016-2019. As a result, we found that firms with a pessimistic tone in earnings announcements more disclose CSR as a tool to distract users. In addition, this study also found that CSR disclosure is higher in firms that use a pessimistic tone in earnings announcements and have a busy CEO. Previous literature stated that busy CEOs would not be able to carry out their functions properly due to the limited energy and time they have [23,24], thereby reducing the firm performance [64-66]. As a result, firms use CSR disclosures with the aim of social legitimacy [33,34], gaining stakeholder trust and consensus [34] and enhancing the firm's reputation [70].

This study has contributed in several ways. First, it contributes to the literature on narrative disclosure and sustainability disclosure. Then, it tries to explain the relationship between pessimistic tone in earnings announcement and CSR disclosure. It helps users identify the tone or style of language used to disclose the income statement narrative in the MD\&A report. In fact, the existence of an MD\&A report increases the degree of transparency and reduces asymmetry information. MD\&A reports with more negative aspects, i.e., pessimistic tone, will have higher disclosure quality, and MD\&A reports with more positive aspects, i.e., optimistic tone, will have lower disclosure quality. To convince stakeholders that the company is in a sustainable condition, the management provides better CSR disclosure to preserve firm reputation

In addition, this research is beneficial for the government, investors, and all stakeholders interested in CSR and narrative disclosure. Government can consider the findings from this study important for the outline of MD\&A reports, as there is no guidance for writing MD\&A reports in Indonesian financial authority regulations. The existence of an outline will make it easier to measure MD\&A report compliance and maintain the level of 
transparency. Meanwhile, for investors, research results can be used to pay attention to the possible specific signals from the use of tone in the narrative reported by the company's management and its impact on financial and non-financial performance.

However, this study has several limitations. First, CSR disclosure is only measured based on the information presented in the sustainability report. According to [25], sustainability reporting was due to become mandatory in 2021 and was delayed to 2022 due to the COVID-19 pandemic. In consequence, a sustainability report is still voluntary in all years of research. So, not all firms issue sustainability reports. Another consequence is that this research cannot capture CSR disclosure information in other sources, such as the firm's website. Second, CSR disclosure is seen in total, not per component [54]. Consequently, this study cannot see the effect of a pessimistic tone in earnings announcements on each component. We recommend future studies to examine the relationship between the pessimistic tone in earnings announcements and each component of CSR disclosure.

Third, the capturing of CSR disclosure as a greenwashing practice is little used in Indonesia due to the limitation of the literature. In addition, this study only captures the higher CSR disclosure components as a tool for preserving company reputation when they signal pessimistic tone in earnings announcement. This finding can be used for future studies to deeply examine whether the higher CSR disclosure components reflect the reality or if it is just a greenwashing practice. We also suggest that future studies consider the use of audited sustainability reports. The audit opinion of the CSR report is critical to see the quality of CSR disclosure and can be used as a benchmark for future research when examining greenwashing practice.

Author Contributions: Conceptualization, S.N. and I.H.; methodology, B.L.; software, N.F.; validation, S.N. and I.H.; formal analysis, N.F.; investigation, S.N.; resources, I.H.; data curation, B.L.; writing-original draft preparation, S.N. and N.F.; writing-review and editing, I.H. and B.L.; visualization, I.H. and N.F.; supervision, S.N. and B.L.; project administration, N.F.; funding acquisition, S.N. All authors have read and agreed to the published version of the manuscript.

Funding: This research has received partial funding support from the Universitas Airlangga, Indonesia, under International Collaboration Grant scheme in 2021.

Institutional Review Board Statement: Not applicable.

Informed Consent Statement: Not applicable.

Data Availability Statement: Not applicable.

Conflicts of Interest: The authors declare no conflict of interest.

\section{References}

1. Mallin, C.A. Corporate Governance, 6th ed.; Oxford University Press: Oxford, UK, 2019.

2. Center, I.W.C. IMD Releases ITS 2016 World Competitiveness Rankings. 2016. Available online: http://www.imd.org/news / IMD-releases-its-2015-World-Competitiveness-Ranking.cfm (accessed on 11 October 2021).

3. KPPU. KPPU: Indeks Persaingan Usaha di Indonesia Masih Rendah. 2016. Available online: https://kppu.go.id/blog/2016/08/ kppu-indeks-persaingan-usaha-di-indonesia-masih-rendah/ (accessed on 11 October 2021).

4. Kothari, S.P.; Shu, S.; Wysocki, P.D. Do managers withhold bad news. J. Account. Res. 2009, 47, 241-276. [CrossRef]

5. Otoritas Jasa Keuangan Republik Indonesia. Peraturan Otoritas Jasa Keuangan Republik Indonesia Nomor 29/POJK.04/2016 Tentang Laporan Tahunan Emiten atau Perusahaan Publik; Financial Services Authority: Jakarta, Indonesia, 2016; pp. 1-29. Available online: www.ojk.go.id (accessed on 11 October 2021).

6. Liu, P.; Nguyen, H.T. CEO characteristics and tone at the top inconsistency. J. Econ. Bus. 2020, 108, 105887. [CrossRef]

7. Buchholz, F.; Jaeschke, R.; Lopatta, K.; Maas, K. The use of optimistic tone by narcissistic CEOs. Account. Audit Acc. J. 2018, 31, 531-562. [CrossRef]

8. Tran, L.T.H.; Tu, T.T.K.; Nguyen, T.T.H.; Nguyen, H.T.L.; Vo, X.V. Annual report narrative disclosures, information asymmetry and future firm performance: Evidence from Vietnam. Int. J. Emerg. Mark. 2021, 502. [CrossRef]

9. Lu, Y.; Cahan, S. Is CSR performance related to disclosure tone in earnings announcements? Account. Res. J. 2017, 32, 129-147. [CrossRef]

10. Osma, B.G.; Grande-Herrera, C.; Saorin, E.G. Optimistic Disclosure Tone and CEO Career Concerns. SSRN Electron. J. 2018. Available online: https: / papers.ssrn.com/sol3 / papers.cfm?abstract_id=3160100 (accessed on 11 October 2021). 
11. Alalwani, Z.; Mousa, G.A. Optimistic disclosure tone in corporate annual reporting and financial performance. In Proceedings of the 2020 International Conference on Decision Aid Sciences and Applications (DASA'20), College of Business Administration at the University of Bahrain, Online, 8-9 November 2020; pp. 1128-1133. [CrossRef]

12. Aly, D.; El-Halaby, S.; Hussainey, K. Tone disclosure and financial performance: Evidence from Egypt. Account. Res. J. 2018, 31, 63-74. [CrossRef]

13. Yekini, L.S.; Wisniewski, T.P.; Millo, Y. Market reaction to the positiveness of annual report narratives. Br. Account. Rev. 2016, 48, 415-430. [CrossRef]

14. Davis, A.K.; Piger, J.; Sedor, L.M. Beyond the Numbers: An Analysis of Optimistic and Pessimistic Language in Earnings Press Releases. 2006. Available online: http:/ / research.stlouisfed.org/wp/2006/2006-005.pdf (accessed on 11 October 2021).

15. Huang, X.; Teoh, S.H.; Zhang, Y. Tone Management. Account. Rev. 2014, 89, 1083-1113. [CrossRef]

16. Augusta, C.D.; DeAngelis, M.D. Does accounting conservatism discipline qualitative disclosure? Evidence from tone management in the MD \& A. Contemp. Account. Res. 2020, 37, 2287-2318. [CrossRef]

17. Gavana, G. Earnings Management and CSR Disclosure. Family vs. Non-Family Firms. Sustainability 2017, 9, 2327. [CrossRef]

18. Hooghiemstra, R. Corporate Communication and Impression Management-New Perspectives Why Companies Engage in Corporate Social Reporting. J. Bus. Ethics. 2000, 27, 55-68. [CrossRef]

19. Bebbington, J.; Larrinaga, C.; Moneva, J.M.; Bebbington, J. Corporate social reporting and reputation risk management. Account. Audit. Account. J. 2008, 21, 337-361. [CrossRef]

20. Ayuningtyas, E.S.; Harymawan, I. Negative Tone and Readability in Management Discussion and Analysis Reports: Impact on the Cost of Debt. J. Manaj. Teor. Dan Terapan. 2021, 14, 129-146. [CrossRef]

21. Harymawan, I.; Nasih, M.; Ratri, M.C.; Nowland, J. CEO busyness and firm performance: Evidence from Indonesia. Heliyon 2019, 5, e01601. [CrossRef]

22. Fama, E.F.; Jensen, M.C. Separation of Ownership and Control. J. Law Econ. 1983, 26, 301-325. [CrossRef]

23. Fich, E.M.; Shivdasani, A. Are busy boards effective monitors? J. Financ. 2006, 61, 689-724. [CrossRef]

24. Di Pietra, R.; Grambovas, C.A.; Raonic, I.; Riccaboni, A. The effects of board size and 'busy' directors on the market value of Italian companies. J. Manag. Gov. 2008, 12, 73-91. [CrossRef]

25. Otoritas Jasa Keuangan. Peraturan Otoritas Jasa Keuangan Nomor 51 /POJK.03/2017 Tentang Penerapan Keuangan Berkelanjutan Bagi Lembaga Jasa Keuangan, Emitten dan Perusahaan Publik; Otoritas Jasa Keuang: Jakarta, Indonesia, 2017; pp. 1-15.

26. Wanqi, L.; Alicia, L.Y.; Thuy, N.T.; Haiyi, P.; Angelica, S.R.X.; Desmond, T.W.L.; Toeh, S.; Aaron, Y.S.T. Corporate Sustainability Reporting in ASEAN Countries; Centre for Governance and Sustainability NUS Business School: Singapore, 2020.

27. Barry, C.B.; Brown, S.J. Differential Information and Security Market Equilibrium. J. Financ. Quant. Anal. 1985, 20, 407-422. [CrossRef]

28. Botosan, C.A. Disclosure level and the cost of equity capital. Account. Rev. 1997, 72, 323-349.

29. Merkl-Davies, D.M.; Brennan, N.M. Discretionary Disclosure Strategies in Corporate Narratives: Incremental Information or Impression Management? J. Account. Lit. 2007, 26, 116-196. Available online: http://hdl.handle.net/10197/2907 (accessed on 12 October 2021).

30. Luo, Y.; Zhou, L. Textual tone in corporate financial disclosures: A survey of the literature. Int. J. Discl. Gov. 2020, 17, 101-110. [CrossRef]

31. Li, F. The information content of forward- looking statements in corporate filings-A naïve bayesian machine learning approach J. Account. Res. 2010, 48, 1049-1102. [CrossRef]

32. Feldman, R.; Govindaraj, S.; Livnat, J.; Segal, B. Management's tone change, post earnings announcement drift and accruals. Rev. Account. Stud. 2010, 15, 915-953. [CrossRef]

33. Loughran, T.; Mcdonald, B. When Is a Liability Not a Liability? Textual Analysis, Dictionaries, and 10-Ks. J. Financ. 2011, 41, 57-59. [CrossRef]

34. Davis, A.K.; Piger, J.M.; Sedor, L.M. Beyond the Numbers: Measuring the Information Content of Earnings Press Release Language. Contemp. Account. Res. 2012, 29, 845-868. [CrossRef]

35. Valta, P.; Paris, H. Competition and the cost of debt. J. Financ. Econ. 2012, 105, 661-682. [CrossRef]

36. Mishra, S.; Modi, S.B. Positive and Negative Corporate Social Responsibility, Financial Leverage, and Idiosyncratic Risk. J. Bus. Ethics 2013, 117, 431-448. [CrossRef]

37. Davis, A.K.; Tama-Sweet, I. Managers' Use of Language Across Alternative Disclosure Outlets: Earnings Press Releases Versus MD \& A. Contemp. Account. Res. 2012, 29, 804-837. [CrossRef]

38. Wu, D.X.; Yao, X.; Guo, J.L. Is Textual Tone Informative or Inflated for Firm's Future Value? Evidence from Chinese Listed Firms. Econ. Model. 2021, 94, 513-525. [CrossRef]

39. Choi, J.; Suh, Y.; Jung, N. Predicting corporate credit rating based on qualitative information of MD \& A transformed using document vectorization techniques. Data Technol. Appl. 2020, 54, 151-168. [CrossRef]

40. Kanbaty, M.; Hellmann, A.; He, L. Infographics in corporate sustainability reports: Providing useful information or used for impression management? J. Behav. Exp. Financ. 2020, 26, 100309. [CrossRef]

41. Siano, A.; Vollero, A.; Conte, F.; Amabile, S. "More than words": Expanding the taxonomy of greenwashing after the Volkswagen scandal. J. Bus. Res. 2017, 71, 27-37. [CrossRef]

42. Delmas, M.A.; Burbano, V.C. Vanessa Burbano: The drivers of greenwashing. Calif. Manag. Rev. 2011, 54, 64-87. [CrossRef] 
43. Seele, P.; Gatti, L. Greenwashing Revisited: In Search of a Typology and Accusation-Based Definition Incorporating Legitimacy Strategies. Bus. Strategy Environ. 2017, 26, 239-252. [CrossRef]

44. Lyon, T.P.; Montgomery, A.W. The Means and End of Greenwash. Organ. Environ. 2015, 28, 223-249. [CrossRef]

45. Marquis, C.; Toffel, M. When Do Firms Greenwash? Corporate Visibility, Civil Society Scrutiny, and Environmental Disclosure; Harvard Business School: Boston, MA, USA, 2012.

46. Terrachoice. The SinS of GreenwaShinG Home and Family Edition. 2010. Available online: http://sinsofgreenwashing.org/ findings/greenwashing-report-2010/ (accessed on 12 October 2021).

47. Elving, W.J.L. Scepticism and corporate social responsibility communications: The influence of fit and reputation. J. Mark. Commun. 2013, 19, 277-292. [CrossRef]

48. Prasad, A.; Holzinger, I. Seeing through smoke and mirrors: A critical analysis of marketing CSR. J. Bus. Res. 2013, 66, 1915-1921. [CrossRef]

49. Walker, K.; Wan, F. The Harm of Symbolic Actions and Green-Washing: Corporate Actions and Communications on Environmental Performance and Their Financial Implications. J. Bus. Ethics 2012, 109, 227-242. [CrossRef]

50. Leonidou, C.N.; Skarmeas, D. Gray Shades of Green: Causes and Consequences of Green Skepticism. J. Bus. Ethics 2017, 144, 401-415. [CrossRef]

51. Fitrianingrum, A.; Celsya, S. Greenwashing, Does it Work Well for Indonesian Millennial Buyers? In Proceedings of the International Conference on Management, Accounting, and Economy, Jakarta, Indonesia, 3-14 February 2020; pp. 157-162. [CrossRef]

52. Martínez-Ferrero, J.; Garcia-Sanchez, I.M.; Cuadrado-Ballesteros, B. Effect of Financial Reporting Quality on Sustainability Information Disclosure. Corp. Soc. Responsib. Environ. Manag. 2013, 22, 45-64. [CrossRef]

53. Falato, A.; Kadyrzhanova, D.; Lel, U. Distracted directors: Does board busyness hurt shareholder value? J. Financ. Econ. 2014, 113, 404-426. [CrossRef]

54. Ratri, M.C.; Harymawan, I.; Kamarudin, K.A. Busyness, tenure, meeting frequency of the ceos, and corporate social responsibility disclosure. Sustainability 2021, 13, 5567. [CrossRef]

55. Hart, R.P.; Carroll, C.E. DICTION 7 Help Manual. Digitext, Inc. 2014. Available online: https://dictionsoftware.com/videotutorials / (accessed on 12 October 2021).

56. Loughran, T.; Mcdonald, B. Textual Analysis in Accounting and Finance: A Survey. J. Account. Res. 2016, 54, 1187-1230. [CrossRef]

57. Fahad, P.; Rahman, P.M. Impact of corporate governance on CSR disclosure. Int. J. Discl. Gov. 2020, 17, 155-167. [CrossRef]

58. Xu, S.; Ma, P. CEOs' Poverty Experience and Corporate Social Responsibility: Are CEOs Who Have Experienced Poverty More Generous? J. Bus. Ethics 2021, 1-30. [CrossRef]

59. Naseem, M.A.; Riaz, S.; Rehman, R.U.; Ikram, A.; Malik, F. Impact of Board Characteristics on Corporate Social Responsibility Disclosure. J. Appl. Bus. Res. 2017, 33, 801-810. [CrossRef]

60. Alyousef, L.; Alsughayer, S. The relationship between corporate governance and voluntary disclosure: The role of boards of directors and audit committees. Univers. J. Account. Financ. 2021, 9, 678-692. [CrossRef]

61. Bose, S.; Ali, M.J.; Hossain, S.; Shamsuddin, A. Does CEO-Audit Committee/Board Interlocking Matter for Corporate Social Responsibility? J. Bus. Ethics 2021, 1-29. [CrossRef]

62. Harymawan, I.; Kristanto, F.; Putra, G.; Fianto, B.A. Financially Distressed Firms: Environmental, Social, and Governance Reporting in Indonesia. Sustainability 2021, 13, 10156. [CrossRef]

63. Wooldridge, J.M. On Estimating Firm-Level Production Functions using Proxy Variables to Control for Unobservables. Econ. Lett. 2009, 104, 112-114. [CrossRef]

64. Hauser, R. Busy directors and firm performance: Evidence from mergers. J. Financ. Econ. 2018, 128, 16-37. [CrossRef]

65. Limbasiya, N.; Shukla, H. Effect of Board Diversity, Promoter's Presence and Multiple Directorships on Firm Performance. Indian J. Corp. Gov. 2019, 12, 169-186. [CrossRef]

66. Saleh, M.W.A.; Shurafa, R.; Shukeri, S.N.; Nour, A.I.; Maigosh, Z.S. The effect of board multiple directorships and CEO characteristics on firm performance: Evidence from Palestine. J. Account. Emerg. Econ. 2020, 10, 637-654. [CrossRef]

67. Ramus, C.A.; Montiel, I. When are corporate environmental policies a form of greenwashing? Bus. Soc. 2005, 44, 377-414. [CrossRef]

68. Zott, C.; Huy, Q.N. How entrepreneurs use symbolic management to acquire resources. Adm. Sci. Q. 2007, 52, 70-105. [CrossRef]

69. Coombs, T.; Coombs, W.T.; Holladay, S.J. The paracrisis: The challenges created by publicity managing crisis prevention. Public Relat. Rev. 2012, 38, 408-415. [CrossRef]

70. Aras, G.; Crowther, D. Governance and the management of global markets. In Developments in Corporate Governance and Responsibility; Emerald: Bingley, UK, 2011; Volume 2, pp. 3-21. [CrossRef]

71. Heckman, J.J. Sample selection bias as a specification error. Econometrica 1979, 47, 153-161. [CrossRef]

72. Katmon, N.; Al, O.; Farooque, O.A. Exploring the Impact of Internal Corporate Governance on the Relation Between Disclosure Quality and Earnings Management in the UK Listed Companies disclosure and governance regime in corporate settings to. J. Bus. Ethics 2017, 142, 345-367. [CrossRef]

73. Al-Shaer, H.; Zaman, M. Audit committee disclosure tone and earnings management. J. Appl. Account. Res. 2021, 22, 780-799. [CrossRef] 